UDC 327:316.776(100)]:791

\title{
UNIVERSAL CODES IN INTERNATIONAL POLITICAL COMMUNICATION: SPECIFIC CASE OF AUDIOVISUAL MEDIA
}

\author{
Yeromin M. B., \\ post-graduate student, Department of International Relations and Foreign Policy, \\ Vasyl' Stus Donetsk National University
}

The article dwells upon the specific case of audiovisual media in a growing area of political studies that emphases on international political communication. The communicative asset of codes and a universality of such is a special focus of the article, with interpretation of audiovisual media researched in the context of political communication.

У статті розглянуто окремий випадок аудіовізуального медіа у зростаючому сегменті політичної науки, який вивчає міжнародну політичну комунікацію. Спеціальна увага приділяється такому інструменту комунікації, як коди та їх універсальність, включно з вивченням інтерпретацій аудіовізуального медіа в контексті політичної комунікації.

В статье рассмотрен отдельный случай аудиовизуального медиа в растущем сегменте политической науки, изучающем международную политическую коммуникацию. Особое внимание уделяется такому инструменту коммуникации, как коды и универсальность таковых, включая изучение интерпретации аудиовизуального медиа в контексте политической коммуникации.

Key words: international political communication, audiovisual media, universal code of movies, political communication research, empirical sources, hybrid wars.

In both general humanitarian studies, as well as political studies, the concept of language has a large importance. However, considering any language could be stripped down to a (seemingly more basic) notion of code, actual studies of code as an important aspect of international political communication are scarce, despite it is rather obvious that they have much potential in terms of both practical use and theoretical dwelling. In specific case of this article (and, in wider sense, preceding research by authors) the problem to dwell upon is how such codes could be translated.

Translations developed to a quite high level over thousands of years and now appear quickly and conveniently, of certain texts and in needed languages. Level of knowledge of the foreign languages among world's population is also progressing, as well. And yet, even in such conditions language barrier, whether it gets thicker or thinner at some places, diverse in its shapes and forms, remains. But there is an idea of a language which is understandable anywhere in the world: analogue of a text, in which at least some key elements would be understood by anyone, won't be lost in translation, no matter which language was it written in. As we mentioned, operating at a level of sub-text, it could be really more adequately referred to as a universal code, but within the practice of audiovisual media it is indeed often called a language. A lot of people are inclined to identify a code as an encryption stressing out the need to "break the code". Partially the thought is right but it has one crucial inaccuracy: in fact encryption is only a situational variant of code, which, especially if it is universal is not necessarily encrypted. While encryption, usually, must protect the information, making it understandable only for a small group of people, which have "the clue", in case of universal code anyone could (and sometimes even should) have it because the code is the method of systematizing of information by improving, simplifying (or, on the contrary, making more difficult) of the source material. As an example, coding of a digital text is nothing more then a simple version of a binary code, which, in its primal state could not be read without some previous preparation, and yet it still will take a lot of time. Coding allows us, with the use of some software elements, analogues of the key, to restructure binary code into any kind of human language. So, certain universal code can be viewed as an instrument of progress, which allows humanity the ability to move forward in a few directions at the same time, among which (importantly for us) is the direction of an international relations. Despite this example is very simplified 
it is still fits the first glance on the aspects, needed for the formulation of a very specific problem: one that something . It should be noted, that, unlike encryption, which is a two-way code, more elaborate non-verbal coding may often involve a vast array of conversions from one to another, such as when Chinese, in which hieroglyphs are symbolizing whole words and not letters need to be transformed into sounds to be translated into Morse code [1, p. 110].

Out of "five notorious codes" formulated by Roland Barthes in "S/Z", hermeneutic, semantic, proairetic, cultural and symbolic. While out of these five our research, rooted deeply in case method, mostly operates within boundaries of the cultural code, audiovisual media's universal code tends use all five codes, converting from one another seemingly at random (or rather in the pattern which is yet to be determined). What we can be sure about is that they're not just intersecting as Barthes suggested for writing, they engage in much more active and undetermined processes, engaging with audience. It needs to be noted that for the sake of highlighting political sub-context, we, for now, will use mostly cultural codes (also known as Voice of Science) as out gateway to understanding of levels on which universal code of movies is operated, although Barthes himself elaborates that all codes are, eventually, cultural [3, p. 18; 21].

A notion of universal language exists and persists in audiovisual media and often finds it way through the words of both theoretical scholars and practitioners of its dominant and earliest form - movies (a term itself derived from the most basic explanation there is for film: moving images; film itself pointing out the material on which such images were put). Being both a theoretician and practitioner, award-winning film director Krzysztof Zanussi, noting the phenomenon of unique international popularity of Pope Johann Paul II in his essay "An Adventure with a Pope" (in which he shares his experiences on creating movies about Johann Paul II quite a few times) wrote: "...thought - which I tried to embody in my movie is connected to the fact that Johan Paul II was incredibly figurative man. His gestures, intonations, mimicry precisely displayed what he wanted to transmit to people, - and that's why, in a shots of his visits there are a lot of details which have much more in them then words said aloud. From time to time it may be only a gesture, or a sudden moment of thinking and his thought is seen in the universal language of images» [2, p. 343].

Zanussi comes from a very specific country and historical background of Poland, but very similar words could be found spoken about absolutely different kind of movies by an all-American film director John Carpenter. "... I think what scares me scares every human on the planet. We're all aware of the forces of darkness, of evil, of loss, death. We know it as little children. I mean, I think all of this is dealt with in Grimm's fairy tales, I think it dealt with in horror movies. Horror is a universal language» [4]. An important component we can see in quotes of both Zanussi and Carpenter is that audiovisual media apply to emotional reaction of the audience which could be understood, to a point, universally. It is quite essential to know that universal language or rather universal code of movies predated and formulated many ways in which we perceive any audiovisual media, including most of the news and political information we receive on a daily basis. Emotion could be a guide and a key to understanding of information in such a code, but in many aspects could also be used to assign a new emotional value, a very manipulative one, to audiovisual content that should mainly be just or mostly informative. That is a common method in hybrid wars and a very evident problem in Ukraine nowadays as we thrive to do something with negative results of years of well-witnessed effects audiovisual media from Russia did with ulterior motives. And we also thrive to produce our own sufficient answer, including in the form of our own, effective audiovisual media.

Audiovisual media, fixation of images on film or videotape and digital images as well is what we mostly talk about in this scientific work, because with civilization evolving we become more and more dependent on what was said in that language, spend more time not only searching for new ways, but developing old, as well. Audiovisual media, in that regard, is produced in almost every possible language, including fictional ones. Internet Movie Database (IMDb) divides languages which are specified as used in different listed audio-visual works into common languages and less-common languages, effectively avoiding the notion of non-common and emphasizing that regardless of how common language is, importance of it in the audio-visual media is entirely a decision of creators. Throughout this article IMDb was used as one of the primary supplementary sources on film industry in general and certain audio-visual works in particular. A large website, available in many languages, it serves as pinnacle of information about movies and interconnected audiovisual works on the Internet, a hub of certain media attention. We have a habit to think of media attention as something led by news coverage, which, surely, could at least be theorized as a true fact of life. But works of fiction may also be a very crucial part of media coverage. And the obvious problem that arises here is that facts of real life are easily replaced by scripted works of fiction, which are, at best, a kind of mythology, somewhat based on the facts of real life. The problem is in the fact we cannot be certain to which extent such formation of digital era mythology could be bended and controlled. Even if it is, to some extent, it seems that processes of media formation in the internet are too chaotic to say for sure and the internet now is a main key to modern audio-visual media, not only holding some new formations on it's own, but also aiding the older formats of television and movies in any possible way, including unprecedented cataloguing of audio-visual media, provided by such resources as Internet Movie Database 
(IMDb) What IMDb essentially does is making anybody capable of providing information about audio-visual media (including, in many cases, that of their own creation) and considering that the website had recently hit a mark of 26 years and is still going strong, lack of attention it receives in scientific circles is rather puzzling, especially since unlike Wikipedia, which is mainly financed by donations, IMDb, being a part of mogul Amazon seeks for another kind of donations - verified information and enthusiasm. IMDb had become not only a very strong part of industry on the international scale, but also an instrument of civilian diplomacy.

It could be especially noted that IMDb lists at least one fictional language - Klingon, originating from the TV series Star Trek (Created by Gene Rodenberry, Produced by Desilu Productions, Norway Corporation and Paramount Television, 1966-1969). Franchise derived from the series is primarily audio-visual and over the years has collected one of the most known, media-friendly fandoms. Use of fictional language is an interesting and important thing to note in regards of cultural contents and their influence on perception of language. Post-modern takes on languages demonstrate that such, while relevant for full understanding of the media, are far from the only.

Australian short film Skwerl (Written by Karl Eccleston and Brian Fairbairn, Directed by Brian Fairbairn, 2011), produced in a fictional variant of English is an interesting example of how perception can be manipulated through the context. One of the goals of that short film, stated openly, is to replicate the feeling of how people not fluent with English perceive that language. That goal was seemingly achieved, as a lot of commentaries on YouTube online screener of the short film are dedicated to the memories of people who become fluent with English and indeed remember perceiving and memorizing incorrect and nonsensical words and phrasing [5].

That before the fluency feeling is quite important for understanding of how specific and universal themes influence people to learn language with key motivation being the need to grasp more of the situations depicted and experienced, so essentially to have more context. Quantity and quality of context, though, might not overlap, producing what could be attributed as a context mismatch - a common problem in movies with reason being poor coordination between setting and the author. Language context of the audiovisual media is a subject quite impressive in its history, covering which is a subject for another day, but we will present a brief outline using a few examples. From the very beginning of visual media becoming relevant piece of cultural establishment, audio-visual content creators - producers, directors and writers were not sure whether movies should have partial audio, only pre-recorded music, or both mixed equally. Eventually the latter has become a pre-dominant form (and a standard for nowadays mainstream media, although cases of both silent and music-driven pieces of audio-visual media, of course are produced even if it is not the most popular artistic decision), but even then, a lot of additional problems were evident. A big number of actors who were stars of the Silent Era on the international scale become less relevant due to not knowing the language and/ or having a thick accent. The very first British sound film, Blackmail (Adapted from the play by Charles Bennett, Written by Alfred Hitchcock, Benn W. Levy and Michael Powell, Directed by Alfred Hitchcock, produced by British International Pictures, 1929) helmed by Alfred Hitchcock and filmed in both silent and sound versions had it's fair share of problems when main star, Annie Ondra was dubbed. As technology at the time was underdeveloped, dubbing booth was done in the special booth installed on-set, an unprecedented move which emphasized the importance of sound on a big budget. World War II fixed some of the gaps, eventually making film industries becoming much more inviting for actors and crew members who were ready to learn foreign language, but Hollywood and British film industry, being the primary examples of commercially successful film industries were quite hesitant. Of course, films which used exotic locations such as The Third Man (Adapted from the novel by Graham Greene, written by Graham Greene, Orson Welles, Alexander Korda and Carol Reed, directed by Carol Reed, produced by London Film Productions), a 1949 classic film set in Post-War Austria, were using local talent, but said film was the first British film ever to be primarily filmed on-location. Situation remained relatively the same through the whole second half of the century, with most of the foreign actors on movies such as Red Heat (Written by Harry Kleiner, Walter Hill and Troy Kennedy-Martin, directed by Walter Hill, produced by Carolco Pictures, Lone Wolf and Oak Pictures, 1988), filmed in Hungary (which stood in for USSR in most of the scenes) learning their lines without really knowing the language as well. On the other hand, history of Red Heat provides a lot of food for thoughts in regards of language barrier and cultural contexts - guerilla-style production of the last shot of the movie, genuinely filmed on Red Square had proven that Austrian-born American bodybuilder and actor Arnold Schwarzenegger was known in the Soviet Union - he had fans who were eager for meet and greet session.

Examples of The Third Man and Red Heat were chosen as they provide a nice succession of political tendencies to observe: British-American co-production filmed in Austria cast local talent in 1949. Arnold Schwarzenegger, born and raised in Austria, is only two years younger then this movie and his generation was not only much more prominent in Hollywood, it was also much more interested in cultural context of the United States of America at a whole. Being a collision of two cultural contexts Schwarzenegger, through his athletic accolades and bright, colorful action movies has become a point of interest himself for yet another 
cultural context - one of the Soviet Union, which had a lot of appreciation for sport due to nation-wide propaganda of such in many shapes and forms, even if Schwarzenegger's movies were mostly too violent for the standards of USSR. The fact that in Red Heat Austrian-American actor portrayed a Soviet policeman blurred the line for many people between the cultural contexts, inspiring generations of young bodybuilders and language learners, sometimes combining the two such as in case of Alexander Nevsky. While English of this notorious actor, writer and producer is almost universally panned as a non-perfect thick accent rendition, it was more then enough to have a technically successful business venture which produces some form of audio-visual media. Films starring (and often produced by) Nevsky, while regarded mostly as mindless b-movies obtained a cult status in specific circles of Russia and United States, additionally providing a lot of fuel in the discussion of what eventually makes cultural contexts different enough and how to mix them well. (Thompson, 2009) Movies often regarded as "bad" by American audiences, while researched enough almost always regarded as such due to a contextual mismatch. Interestingly enough such notoriety appeals to people, with one particular example of a notoriously bad movie, The Room (Written and directed by Tommy Wiseau, Produced by Wiseau-Films, 2003) often regarded as somewhat of a cult phenomenon. The main driving force behind the movie is Tommy Wiseau, who is, not unlike Arnold Schwarzenegger, become an American through cultural context eventually re-shaping his role and identity model. The world and situation he creates have a very slippery threshold of realism - Wiseau himself, while being massively appealed to cultural context of living in America and speaking English falls short into portraying both in his movie, despite also being a director of documentary aptly named Homeless in America [6].

Political studies in international relations, a native research field for authors of this chapter has proven itself to crucially depend on language learning, to the point that such requires more then a half of speciality curriculum. One of the main goals here is to make students flexible towards sources in foreign languages, making them not as "foreign" for them in their own studies. That is a crucial part of political studies because politics in the modern world require and crave for international cooperation on any level. Closed countries do not develop as steady and fast as they might have due to close borders, but some of these borders are closed from the inside and are not governmental restrictions per se. Language barrier has become a serious problem to fight with in the developing countries due to the fact that it mutually restrains international cooperation and that aspect, eventually, hurts economic, diplomatic and even cultural aspects of developing.

Political studies are, to some point, is a glue, that bonds together different aspects of developing and classifies them accordingly to some wide-spread political doctrines. Knowing how such doctrines inspire certain concepts in the everyday life of the state, how they transform in society's conscience and eventually inspire nation-wide processes is what political studies should concentrate upon and that also might include inspiring the needed and very welcome change in what is known as technology-enhanced language learning (TELL). Studying universal code of audio-visual media in the contexts of International political communication should be taken into consideration in TELL and research thereof, as nowadays people tend to be much more politically involved with the use of Internet and social networks as instruments of political influence, discussion and education - wider then ever and yet also much more restricted then before. Correlation between audio-visual media and new media social platforms, such as Reddit seem to be overlooked and under-researched. Present-day learners are represented mostly by the members of the Facebook/ YouTube generation which is more visually developed than whichever of the previous generations. For this generation, online communication via exchanging static and moving images is just as important as faceto-face interaction, often offering knowledge-exchange opportunities. Their expectations strongly influence the modern teaching style by demanding more and more visual aids (first of all films) especially in teaching foreign languages.

Social platforms such as Reddit, YouTube and Facebook can, through the use of unconventional methods of collective conjunction (in cultural and informational aspects) be a potentially beneficial field of study. Given that it achieves theorizing it lacks nowadays, because of speed, with which new elements affect the global systems of both information and culture, as well as subcultures and what we may name temporarily as subinformation. In its modern form communication itself is an underdeveloped quasi-concept (a not yet formulated image of what one day could become a genuine concept, but for now lacks needed body of work which may took years and years of research. [8], interpreted differently from each new perspective and lacking complexity, which only years of research and systematizing, after meticulously comparing and collecting the empiric facts, could possibly provide.

A whole level of information previously disregarded by political studies is what evident through the drawn examples. Scarce coordination between a vast array of cultural studies and political studies prevents us from noticing relevant information which could have been used for up-to-date and very serious forecasting of events. Considering that nowadays popular culture grows on a plain new international, interactive level, influence of media of which audiovisual one is one of the most effective and dominant could not $b$ ignored in the political studies of international relations. 
Control over the audiovisual media via standard measures such as censorship is not of much help in modern-day society. In order to make situation more effective and controllable required component is not in the area of restricting the artists and entertainers, but in a consideration of an "artistic filter», as a very important and influential layer of international information, while also what is needed to be found is what exactly influences events on a political scale. Such an understanding is impossible without certain universal codes, as we can't understand outline of specific cases without knowing the specs on how the system of audiovisual media works. That also requires taking into a consideration the fact that nowadays market of such re-shapes rapidly, providing massive abilities for independent media outlets to be as influential as news media and big-time Hollywood studios.

For political studies in the international relations, audiovisual media, while not exactly being terra incognita, is a place of only a certain level familiarity, which could and should be enriched by further research, as security of the situation pretty much depends on intricate processes of international communication witnessed in a conglomerate of social media and audiovisual media. Already, a situation of hybrid war forming within our own country dictates the need of closer filtration of information provided to us through the social networks, which nowadays, primarily, tend to use audiovisual format to stay fast and relevant. Relevancy of audiovisual media, its whole survival through the years and even decades (centuries are certainly out of question as audiovisual media is much younger then printed one) depended on being fluid, adaptive and developing a very transformative and unique system of approaching the unsuspecting audience from every corner. That resulted in supposed simple entertainment becoming not just one, but several multibillion industries, which intervene in unexpected way when it comes to presenting actual events and then distorting the accounts in latter, fictionalized attempts.

However, at this day and age the line between the two is quite a ghostly one, with news relying on methods invented in movies to stay understandable and effective at engaging audience, movies emulating the style and contents of news to stay relevant and, finally, new media of the Internet (which were largely out of the picture only a few years prior) using methods of both to form a useable niche within the larger audience, which at times eventually influences the latter in unpredicted and often barely traceable ways.

\section{References:}

1. Горелов И.Н., Енгалычев В.Ф. Безмолвный мысли знак: Рассказы о невербальной коммуникации. Москва, 1991. 240 с.

2. Зануссі К. Час помирати: Спогади, роздуми, анекдоти. Харків, 2013. 478 с.

3. Barthes R. S/Z. Translated by Richard Miller. 2002. Oxford: Blackwell Publishing. 271 p.

4. Carpenter J., Hill D., Curtis J.L. Audio Commentary // Halloween H25 [Електронний ресурс]: аудіовізуальні медіа. Anchor Bay Entertainment. Beverly Hills, 2003. 2 електрон. опт. диски (DVD).

5. Rao M. "Skwerl": Fake English In A Short Film // Huffington Post: електронне видання. 2011. Дата оновлення: 31.10.2018. URL: https://www.huffingtonpost.com/2011/10/13/fake-english-shortfilm_n_1008785.html.

6. Thompson K. From Russia, with muscles: Movie starAlexander Nevsky//The Palm Beach Post: електрон. версія газ. 2009. Дата оновлення: 31.10.2018 URL: https://www.palmbeachpost.com/entertainment/ movies/from-russia-with-muscles-movie-star-alexander-nevsky/IFCuiQhZ37ZaJ20AUgdVuN/.

7. Yeromin M., Charskykh I. Use of the codes of audio-visual media: strengthening the sub-lingual international communication in higher education Multiculturalism and technology-enhanced language learning. 2017. Hershey, PA: IGI-Global. C. 68-82.

8. Jenson, J., Harrison, D., Prange-Gstöl, H. Social innovation research in the European Union. Approaches, findings and future directions. Policy Review. Luxembourg, 2013. 